\title{
Legal Consequences of the Determination of Corporate Income Tax Base Referring to IFRS $^{\#}$
}

\author{
Jan Molín ${ }^{*}$ Simona Jirásková ${ }^{* *}$
}

\section{Introduction}

Like in other countries, corporate income tax is a standard tax collected in the Czech Republic. Revenue from the tax accounts for approximately $17 \%$ of aggregate tax income (net of social security contributions and health insurance premiums).

For those payers, who keep accounting records, the calculation of tax base stems from the accounting profit, which is subsequently adapted by a number of taxable and deductible items. In the last few years, some rulings of the Supreme Administrative Court drew attention. The Court examined in several of its judgements the relationship of an accounting profit and income tax base, discussing in particular whether all revenues of an accounting entity should be included in its tax base (naturally unless otherwise stipulated in the specific case, i.e., when certain revenue is exempt from tax), or not.

The objective of this article is to examine the determination of corporate income tax base in the Czech Republic from the legal point of view. In terms of its structure, the article first discusses general topics, i.e., definition of the term "tax", and the constitutional basis of tax collection. This is followed by an analysis of issues pertaining to

\# This article has been prepared under the research project Assumptions for Introduction of the IFRS as an Alternative Tax Base in a Small Open Economy: Evaluation of Its Impact on Country's Competitiveness supported by the Czech Science Foundation under the registration number P403/12/1901.

Ing. Jan Molín, Ph.D. - Senior Lecturer; Department of Financial Accounting and Auditing, Faculty of Finance and Accounting, University of Economics, Prague, W. Churchill Sq. 4, 13067 Prague 3, Czech Republic; <jan.molin@vse.cz>.

** Ing. Simona Jirásková - Ph.D. Student; Department of Financial Accounting and Auditing, Faculty of Finance and Accounting, University of Economics, Prague, W. Churchill Sq. 4, 13067 Prague 3, Czech Republic; <qjirs01@vse.cz>. 
corporate income tax in the context of present legal regulation. Furthermore, we address specifics of taxation by those taxpayers who apply International Financial Reporting Standards in the compilation of their financial statements, both from the point of view of existing and future legal regulation. The analysis of legal background of taxation in relation to corporate financial reporting using the methods of jurisprudence extends the current research focusing on the characteristics and effects of various approaches to book-tax conformity. The paper may thus contribute to our knowledge of specifics of book-tax conformity esp. in transition countries, which are unique by their unbalanced institutional environment (relatively negligible capital markets; significant influence of foreign capital investors; interference of fiscal measures into financial reporting; etc.).

The paper is organised as follows. Chapter 1 defines the term "tax" and discusses the constitutional dimensions of taxation. We also analyse the desirable requirements on sound tax legislation. Chapter 2 introduces the structure of corporate income tax base in general and explores the relationship of revenues (from accounting point of view) and taxable income. In Chapter 3, we outline possible (future) changes in tax system referring to the paper's findings, which may improve the current state of the art.

In the context of used methodology, the paper uses the qualitative one. We have studied a literature and other sources and we discuss them in a context of our own research. We use the method of deduction, analysis and synthesis. We have also used a comparative analysis.

\section{Legal Aspects of Tax Collection in the CR}

\subsection{Briefly on the Definition of the Term Tax}

Various encyclopaedias and publications feature different definitions of the term tax. Certain older sources, such as the encyclopaedic dictionary Ottův slovník naučný, define the tax (berně) as a "contribution that individuals must pay to public finances, the state, the land, the district, the municipality, etc., for the coverage of the general needs of those public estates". It also adds that the purpose of a tax is "primarily to pay general expenditures of the public finances of the state, land, etc., whereby it differs from a fee which is used as a payment for special expenses, that is, the costs of maintaining state authorities whose activities are based on the actions being paid for. Aside from this purpose, 
the imposition of a tax may pursue other purposes, primarily ethical, to prevent certain facts that may have an impact on the vanity of the population (the imposition of a tax on luxury), or ethical and medical purposes (e.g., a tax on alcoholic beverages)." (Ottův slovník naučný, 1893, pp. 928).

Smith (1776) declared in book V main principles on the payment of taxes: proportionality, transparency, convenience, and efficiency. These principles are still to present days the most important „maxims“ for tax policy and strongly influence also systems of accounting. Ricardo (1817) in chapter VII discusses taxes mainly from the classical point of view, e.g. analyse distribution of tax burden between land product ("revenue of the country") and capital. He often concludes that taxes reduce capital accumulation and therefore should be mineralised.

In terms of theory, there is a general agreement - see e.g., Kubátová (2006, p. 16) and Vančurová - Láchová (2010, pp. 9-12) - that tax is a payment to a public budget that has the following qualitative properties:

- it is an obligation (meaning a statutorily imposed legal obligation to pay);

- it is non-refundable;

- is purpose is not specified; and

- it is non-equivalent.

As it can be inferred, a distinction must be made between the term tax in legal terms (see below) and in economic terms, when it includes other payments to the public budget, which - although not designated as a "tax" - manifest the properties specified above. Customs fees may be an example.

\subsection{The Constitutional Dimension of Taxation}

Given that by taxing entities, the state de facto takes away a portion of their property, which may generally seem like an intervention in their fundamental rights and freedoms, it is necessary to examine the constitutional dimension of tax collection. In the Czech Republic, the resolution of this problem ${ }^{1}$ is based on the maxim embodied in Article 2

1 Similar pattern is experienced in other European countries as well (e.g., Kmec, 2012, pp. 1243 and ff.). 
Molín, J. - Jirásková, S.: Legal Consequences of the Determination of Corporate Income Tax Base Referring to IFRS.

(3) and (4) of the Constitution of the Czech Republic (Constitutional Act No. 1/1993 Coll., as amended). According to these Articles, the state power can only be exercised in cases, within the bounds, and by the means stipulated by law (unlike the actions of citizens, who can do everything that is not prohibited by law). Tied to this rule is the provision of Article 11 (5) of the Charter of Fundamental Rights and Freedoms (Constitutional Act No. 2/1993 Coll., as amended), from which it flows expressis verbis that taxes and fees can only be imposed by an act. ${ }^{2}$ The Charter of Fundamental Rights and Freedoms does not define the terms "tax" and "fee" in detail and does not enumerate what taxes and fees can be collected. However, as Pavlíček (2004, pp. 112) points out, the sovereignty of a state does not give the state the option to impose any taxes, albeit on the basis of an act, but in the tax area, the law-giving body must base its decision on objective and rational criteria.

In the context of the legal regulation of taxation, we must keep in mind that a state professing the rule of law is obliged to formulate legal provisions (including tax laws) as tightly as possible. If the state is unable to do so, the problem is on its behalf (Melzer, 2011, pp. 208). From this flows the requirement "in dubio mitius", which means that in the event of doubt, a specific provision has to be interpreted less strictly, i.e., in favour of the preferred party, usually the addressee of the power-based action of the state, that is, the taxpayer. Melzer (2011, pp. 208) asserts that "If we are (in the case of legal doubts, auth. note) to decide between an interpretation that is favourable for the state and one that is favourable for the addressees of a legal regulation, we must opt for the second option." Moreover, he concludes, "actually, the reason for legitimisation is the protection of legal certainty." If the addressee of regulation interprets a certain provision at least within the bounds of an objectively

2 In this context, the term "act" must be understood more broadly. According to the provisions of Article 33 (1) of the Constitution of the Czech Republic, if the Chamber of Deputies is dissolved, the Senate is authorised to enact statutory measures in urgent matters, which would otherwise require the enactment of an act. In recent past, this procedure was used in substantive tax law as Senate Statutory Measure No. 340/2013 Coll., was enacted, which regulated the new tax on the acquisition of real property, replacing the existing legal regulation of real estate transfer tax. The authors of this contribution concur with certain sceptical conclusions that it is uncertain whether the statutory measure met the condition of "urgency" as it is generally explained for example by Sládeček (2007, pp. 257): "It means that all matters that are regulated by the statutory measure must be so pressing that they cannot be regulated by an act once the newly elected Chamber of Deputies convenes a session." 
recent interpretive target methodologically correctly, (s)he has the legitimate expectation (good faith) that if (s)he acts in line with that interpretation, (s)he acts in line with the law."

Related to the above requirement is the issue of subsequent formation of (tax) law. As for example Harvánek explains (2013, pp. 347), unlike in the interpretation of law, which was discussed above, legal norms can be subsequently formed to fit the conditions of a specific case. This is processed through the implementation and application of law in certain cases when the interpreting party cannot succeed in it within the bounds of the meaning of a legal text. This is called subsequent formation of law, and judge-given law. The primary tool of such subsequent formation is analogy (i.e., inferring a legal rule for cases not regulated by law from a similar case). In the context of tax law, it can be concluded, in connection with the above-mentioned provision of Article 11 (5) of the Charter of Fundamental Rights and Freedoms, that the subsequent formation of law is not possible, as has been inferred for example by the Constitutional Court. $^{3}$

\section{Corporate Income Tax and Calculation of Tax Base}

\subsection{General Notes on Corporate Income Tax and Tax Base Structure}

Corporate income tax in the Czech Republic is regulated by the same act as individual income tax; namely, the Act No. 586/1992 Coll., on income taxes, as amended (hereinafter referred to as the "Income Tax Act"). In line with Section 18 (1) of the Act, the subject of corporate income tax is income from all activities and dispositions with all assets, unless otherwise stipulated.

In this context, we must examine how tax base is defined. The answer captures the Section 23 (1) of the Income Tax Act. It states in general manner that the tax base is the difference by which income, with the exception of income that is not subject to tax and income that is exempt from tax, exceeds expenses (costs), respecting their factual and temporal connections in a given taxable period. In the case of a taxpayer, which is

\footnotetext{
See Constitutional Court ruling file no. I. ÚS 22/99, which in a specific case, pertaining to the assessment of real estate transfer tax examined the normative nature of footnotes to a legal regulation.
} 
Molín, J. - Jirásková, S.: Legal Consequences of the Determination of Corporate Income Tax Base Referring to IFRS.

an accounting entity, such income is the payer's revenue and such expenses are its costs. ${ }^{4}$

Similarly to other countries (Široký, 2013); the tax base of taxpayers keeping accounting records is grounded on the difference between their accounting revenue and expenses (costs), i.e. on their accounting pre-tax profit. Kubátová $(2006$, p. 194) adds to this that in certain countries, accounting profit is significantly adjusted to calculate the tax base, while in other countries (such as Germany), taxable income is nearly equal to accounting profit.

In the Czech Republic, the reconciliation of accounting profit to the income tax base follows primarily the Section 23 (3) and (4) of the Income Tax Act. The volume of items that increase or reduce accounting profit has been more important in recent years in terms of taxation that the profit itself (Vítek, 2013). A general scheme of the formation of the tax base is presented in Tab. 1.

\section{Tab. 1: Structure of the income tax base of those payers who constitute an accounting unit}

\begin{tabular}{|l|l|}
\hline \multicolumn{2}{|l|}{ Profit / loss before tax } \\
\hline- & Exempt income \\
\hline- & $\begin{array}{l}\text { Income not included in the tax base (including separate tax } \\
\text { bases) }\end{array}$ \\
\hline- & Netting of reserves and adjustments not recognised as taxable \\
\hline+ & Accounting costs that are not recognised as tax deductible costs \\
\hline$+I-$ & $\begin{array}{l}\text { Elimination of posted items that are only included in the tax } \\
\text { base if they have been paid }\end{array}$ \\
\hline$=$ & Tax base \\
\hline
\end{tabular}

Source: Vančurová - Láchová (2014, pp. 94).

4 With respect to that, we must note that until 31 December 2013, the legal regulation was somewhat different. "The tax base is the difference by which income, with the exception of income that is not subject to tax and income exempt from tax, exceeds expenditures (costs), respecting their factual and temporal links in a given taxable period, adapted pursuant to the paragraphs below." See below for reasons for the change in legal regulation as of 1 January 2014 and the authors' opinion on the change. 
In this context, we would also like to discuss aim of tax system in comparison with aim of financial reporting. The objective of financial reporting is to provide information for the purposes of monitoring and control, while the aim of the tax system is, simply put, tax collection. Financial and tax accounting cannot be unified, because they have different objectives, they are subject to different rules and serve different purposes. For additional objectives of the tax system of the country can be considered, in particular: optimal allocation of resources among public and private consumption, redistribution of income through taxes and transfer payments and stabilize the economy (James, 2002).

The objectives of financial reporting are quite different from those of the tax system. Framework IASB (International Accounting Standards Board) states that the objective of financial reporting is to provide information about the financial position, performance and changes in financial position of the enterprise that is useful to a wide range of users, and perform economic decisions (Aisbitt, 2002).

\subsection{Discussion of the Term "Income" and the Accrual Principle in the Tax Area}

As was stated above, the subject of corporate income tax is income from all activities and dispositions with all assets. In this regard, the essential matter, also with a view to the law-finding process discussed above (the interpretation and subsequent formation of law), is what exactly can be subsumed under this definition. In other words, whether the term "income" according to the Income Tax Act can actually be aligned with the category of accounting revenue in the sense, in which it is understood by the (above-mentioned) provision of Section 23 (1) of the Income Tax Act.

In the past, these discussions were led primarily in application practice and were the subject of several decisions of the Supreme Administrative Court. The Court discussed the term in several of its decisions, and it always emphasised that in order for income to fall under the income tax definition (both individual and corporate income tax), the income must also be actually reflected in the taxpayer's assets. In its Judgement 1 Afs 48/2007-63 of 12 September 2007, the Supreme Administrative Court inferred, for example, that the tax obligation may be in a "just balance between the interest of society and fundamental rights and freedoms of a person only if it is derived from actual "income" that brings the taxed entity an actual increase (revenue, profit, benefit, other 
Molín, J. - Jirásková, S.: Legal Consequences of the Determination of Corporate Income Tax Base Referring to IFRS.

asset increase), whether in the form of financial accruals or their equivalents, and which must be actually manifest in the actual legal sphere of the entity. Furthermore, this income must not be exempt from tax." In connection with this concept, the Supreme Administrative Court explicitly discussed, in another one of its decisions, in case no. 5 Afs 56/2012-37, dated 25 January 2013, the relationship of the accounting category of revenue and income as the subject of income tax. It inferred that taxable revenue entering the tax base must be "an income (revenue) compliant with the definition of Section 18 (1) of the Income Tax Act. That means that an income is only taxable pursuant to the Income Tax Act if the income (revenue) comes from an activity or from dispositions from assets. That, after all, corresponds to the income-tax concept taxing economic activity rather than asset substance."

The principal case that gave rise to the above-mentioned discussions on merits and raised disputes across the profession pertained to so-called unrealised exchange rate differences reported as gains in accounting profit. ${ }^{5}$ In the case at hand, the taxpayer was in dispute with the Financial Directorate for the City of Prague. They argue whether a reported unrealised exchange rate gain arising from a loan denominated in a foreign currency constitutes an income subject to income tax. In its decision, the Supreme Administrative Court pointed to many facts, including the different objectives of accounting and taxes. The Court inferred that unrealised foreign exchange rate gains could not be equal to income as defined by the Income Tax Act. The Court argues that " $a$ change in an exchange rate in itself does not mean that the complainant achieved an income in the form of a saving in the taxable period concerned, meaning that it would expend fewer crowns on the repayment of its obligation. In economic and legal terms, taxation of exchange rate differences before they are actually realised has no foundation, it is only fictitious "income. .... In essence, it is an expression of the value of assets rather than an actual income or revenue the achievement of which is the result of the activity of the tax entity or of its dispositions with its assets (Section 18 (1) of the Income Tax Act). The source of taxation is factually the payer's own assets, which is not compliant with the concept of income tax. An increase (decrease) in the value of assets depends absolutely on facts independent of the will of the tax entity, which are variable in time,

5 The analysis of accounting treatment of unrealized exchange rate differences can be found e.g. in Pilařová - Pilátová (2013, pp. 37-38). 
i.e., on the current currency rate, i.e., on the policy of the state. A currency conversion only expresses the current value of existing assets (which may be totally different the next date), but not its actual increase." The decision of the Supreme Administrative Court in its Judgement no. 5 Afs 45/2011-94 of 19 April 2012 raised the reaction by professional bodies. An interesting response was formulated e.g. by the National Accounting Council (2012).

The findings occurring in the process of finding law in tax issues imply that a fundamental problem is the absence of a legal definition of the term income (in relation to its taxation). We must concur with the conclusions indicating by Jaroš (2013, pp. 39). To decide whether particular revenue is taxable, it must be tested if it meets the general requirement of being an income "from an activity" or income "from dispositions with assets", i.e., whether the said income meets the conditions set out in Section 18 (1) of the Income Tax Act. In this regard, the constitutional embodiment of tax collection, discussed above, is essential. It has to be recalled that taxes can only be imposed based on an act that has passed through a standard legislative procedure. As the Supreme Administrative Court states in Judgement no. 5 Afs 56/2012-37, of 25 January 2013, "it is absolutely impermissible for the subject of taxation, i.e., the item that is to be taxed and taken away from an individual, to be determined by any other means, which are not, furthermore, within the law-making power, but within the executive power. ${ }^{6}$... In that case, the constitutional principle of division of powers is violated." For the reasons stated, the authors of this contribution believe that the amendment of the Income Tax Act by means of the Senate Statutory Measure 344/2013 Coll., which strove to define the word income in Section 23 (1) such that it is accounting revenue, seems ineffective.

Following the issue addressed above, it shall be to what extent we can talk about the application of the accrual principle in the income tax sphere (or, more precisely, in the case of taxpayers, which keep accounting records). It can be inferred that the accrual principle, which is primarily an accounting principle, has always been respected in tax rules. The interconnection stems from the explicit regulation embodied in Section 23

6 In the sphere of legal regulation of accounting, many interesting topics - for example the posting of revenue - are regulated by Regulations of the Ministry of Finance of the Czech Republic (auth. note). 
(1) in fine of the Income Tax Act, naturally unless it was stated otherwise in a specific case and unless the principle was replaced by another principle (usually referring to the cash basis, as in the case of contractual sanctions, etc.). Similarly, we must concur with the conclusions pertaining to exceptions from the principle transferable to taxes as they are formulated by Pelc and Pelech (2014, pp. 361), Dvořáková (2013, pp. 103-104), or certain older sources, which are, however, still relevant in this regard, e.g., Müllerová and Vančurová (2006). With a view to the issue of the relationship of accounting revenue and taxable income discussed above, which is hugely influenced by the case law of Supreme Administrative Court, we must conclude that the accrual principle is not fully transferrable to the tax field.

\subsection{Tax Base Structure of the IFRS Entities}

It was explicitly stated above that the structuring of the corporate income tax base is based on accounting profit before taxation, which is subsequently adjusted appropriately for tax purposes. After all, this is foreseen by Section 23 (2) (a) of the Income Tax Act.

The said provision also defines the rules according to which an accounting profit is determined, considering only Czech accounting regulations relevant for the corporate taxation. It explicitly states that a taxpayer, which prepares its statutory financial statements in compliance with the International Financial Reporting Standards as adopted by the European Community law, shall use, for the purpose of the Income Tax Act, a special regulation for the determination of its accounting profit and for determining other facts decisive for the calculation of its tax base. Those special regulations are the Czech Accounting Standards, which are issued by the Ministry of Finance of the Czech Republic. This means that it is explicitly ruled out for taxpayers applying International Financial Reporting Standards (further IFRS) in their statutory accounting to use the IFRS profit in determining their corporate income tax base. Let us note that pursuant to Section 19a (1) and ff. of Act No. 563/1991 Coll., on accounting, as amended, this procedure is relevant (mandatory) for corporations that issue securities accepted for trading on the European regulated market, and voluntary in certain other cases. For more on this issue, see Dvořáková (2011) and Vašek (2013).

It can be inferred from the above that such taxpayers (accounting entities) must use the rules set out by International Financial Reporting Standards for compiling their individual financial statements, but for the 
purpose of taxation, they must apply Czech accounting regulations, i.e., their "Czech" profit or loss and rules for adapting those results to achieve the income tax base.

The conversion of financial statements according to Czech accounting regulations into IFRS financial statements and vice versa is not an easy task (e.g. Mejzlík, 2006a; Mejzlík, 2006b). The Ministry of Finance of the Czech Republic, therefore, issued a communication published as Guideline D-295, concerned primarily with the demonstrability of differences between profit or loss determined pursuant to International Financial Reporting Standards and Czech accounting regulations. The Ministry of Finance interpreted that if there is a difference in the posting of individual accounting records between both sets of accounting standards, it is necessary:

- In addition to the IFRS based posting, the corresponding accounting documents shall be added by the relevant numbers of accounts to be credited or debited in case of Czech accounting regulations, and if the amount differs, the amount shall be added, too.

- To make further records of facts subject of accounting, in a manner that corresponds to accounting methods and records in the main ledger and the analytical account ledger. It shall be used a structure stipulated by special legal regulations for an accounting unit that is a business corporation but that has not issued securities registered on a regulated securities market in European Union member states (i.e. in the same manner as non-IFRS entities).

- Draw up an overview, which content and structure corresponds to the profit and loss statement that an accounting unit that is a business corporation but that has not issued securities registered on a regulated securities market in European Union member states is obliged to compile in line with Czech accounting regulations (i.e. in the same manner as non-IFRS entities). 
Molín, J. - Jirásková, S.: Legal Consequences of the Determination of Corporate Income Tax Base Referring to IFRS.

\section{Discussions de lege ferenda}

The present procedure of structuring the income tax base by those taxpayers who apply the IFRS in their statutory financial statements is not random. The primal concern of the state is to maintain control over tax collection (Fučík, 2012). As it has been already stated in several places in this article, it is the state, or, more precisely, its executive power, that has a fundamental impact on accounting (in the form of Czech accounting standards) as the basis for taxation.

This motivation seems justified to a certain extent. We can imagine a situation when - if we admitted the possibility of using accounting profit determined pursuant to IFRS in the determination of the tax base - a change in the rules pertaining to assessing the performance of an accounting unit could have a fundamental impact on the collection of corporate income tax in the short term. In this regard, we must state that such changes in rules have occurred, see for example Procházka (2014).

On the other hand, in the context of current Supreme Administrative Court decisions, it can be said that the current regulation of accounting is problematic with regard to direct taxation of Czech companies. We have explicitly stated that we see as problematic the fact that the subject of taxation is to be influenced by a component of the state's executive power through a sub-statutory legal regulation, namely by laying down (changing) the legal regulation of accounting. A contrario, it can be inferred, in our opinion, that an approach conforming to the Constitution would be for accounting rules, including for the purpose of determining the tax base, to be formed and amended by the profession itself (for more on this see for example Mejzlík - Žárová, 2010 or Mejzlík, 2011 or Skálová - Žárová, 2013).

It may appear a logical conclusion appealing for the possibility of using the IFRS profit in determining corporate income tax base. This would result not only in a lowering of the administrative burden taxpayers and state as well (Tepperová - Kubantová, 2013), but also in a procedure that would better comply with the constitutionally stipulated conditions for tax collection. On the other side, this procedure respecting the simplicity and legal certainty of taxation may contradict another principle of optimal taxation, namely equality (Oestreicher - Spengel, 2007).

The above discussions have been, naturally, conducted in other countries, as well (see e.g., Eberhartinger - Klostermann, 2007, and for a discussion on conclusions pertaining to the Czech Republic see 
Müllerová, 2008). They are to a certain extent related to the adaptation of national accounting rules to the rules of the International Financial Reporting Standards (on more on this see Žárová - Mejzlík, 2011 or Žárová - Mejzlík, 2009a or Žárová - Mejzlík, 2009b).

In this context, Austrian and German experts have carried out research that aimed to analyse the impact of adopting IFRS profit or loss as a wayout for taxation on tax collection. The authors chose for their work several countries - the Czech Republic, Austria, Belgium, Hungary, Ireland, Latvia, Poland and Slovakia. The conclusion of the study says that, apart from Ireland, all other countries using IFRS for taxation would record a slight tendency to increase the tax base and therefore tax collection. They find that there is a large dispersion of effective company tax burdens between the considered countries. An exclusive harmonisation of the tax base by introducing IFRS as a starting point, however, will not significantly reduce the current EU-wide differences of effective company tax burdens. According to their results, the effective tax burden tends to slightly increase in all countries except for Ireland because IAS/IFRS-based tax accounting would broaden the tax base compared to current national accounting rules (Jacobs - Spengel - Stetter - Wendt, 2005).

Deborah Schanz and Schanz (2010) went further in her research. She tried to establish the new method of tax base calculation - significantly separated from the accounting. She finds that in most sectors, the distribution of the relative differences of future values of the cash flows, plus changes in inventories, minus depreciation, minus provisions, tax base dominates the other distributions. This means that this tax base definition arouses the smallest differences in the tax burden of companies even though the tax base consists of fewer elements compared to current commercial and tax law. Implementing this tax base avoids major shifts in the tax burden of different industries. This simplified tax base would cause a huge decline in both tax compliance costs and tax planning costs, because the number of tax base elements that deviate from cash flows is reduced when compared to current tax law. The cash flow tax base, which is very simple to calculate, leads always to higher positive differences. This model is based on empirical data form various industries in Germany.

Practically, the provisions of Section 23 (2) of the Income Tax Act would need to be amended. If the state aimed at achieving, in the short term, identical tax revenue from corporate income tax regardless 
accounting regime used by the taxpayers, several changes has to be made. The changes shall be introduced for both cases, i.e. the structure of tax base needs to be redefined both for entities reporting under IFRS and for entities using Czech accounting regulations as well. An alternative option is that fundamental differences in the concepts are not determined, referring to the assumption that in the long-term the tax revenue would be identical in both cases.

We hold that a change in the legal regulation of income tax is inevitable and the change cannot be just a formal one. Assuming that corporate income tax should conceptually reflect the performance of an accounting unit measured by its profit, the existing legal regulation does not seem to conform fully to this objective.

\section{Conclusion}

Tax is usually defined as a mandatory, non-refundable and nonequivalent payment to a public budget made for an unspecified purpose. The substance of taxation from this point of view is the fact that the state de facto intervenes in the property of individual entities. Hence, constitutional-law requirements indicate that tax collection must be regulated by acts, not through legal regulations of a lesser legal force. One of those acts, and taxes collected in the Czech Republic, is the Income Tax Act and the corporate income tax. The general subject of that tax is income from all activities and income from dispositions with all assets, unless otherwise provided. Simultaneously, the determination of tax base for those taxpayers that are accounting entities is based on their accounting pre-tax profit.

This relationship has been the subject of Supreme Administrative Court decisions in recent past. In several of its judgements, the Court examined the general issue of the relationship of accounting revenue and income that is subject to corporate income tax, always examining a specific example. The best-known "representative" is the case concerning unrealised exchange rate differences gains. In the context of the case law of the Supreme Administrative Court, it must be concluded that the term revenue as an accounting category and the term income as the subject of corporate income tax cannot be considered generally identical. This is because in order for specific revenue to become the subject of income tax, it must be realistically reflected in the asset sphere of the taxpayer, it must constitute its income (within the meaning of the subject of income tax) from its activity or from dispositions with the payer's assets. In the case at 
hand, the Supreme Administrative Court concluded that unrealised exchange rate profit does not constitute such income.

The issue at hand can also be seen from the constitutional point of view. It can be stated that a problem of the current legal regulation of income tax is not only the absence of a legal definition of the term income, but also the possibility of the executive power intervening (outside of the standard legislative process of legal enactment) in the sphere of taxation by changing accounting rules. It seems to us that a more constitutionally conforming solution would be for the area of accounting to be regulated by the profession itself.

Related to this is the question how those payers who compile their financial statements pursuant to International Financial Reporting Standards proceed in determining their tax base - it can be concluded that such payers must use their profit determined according to Czech legal regulations. This leads to de lege ferenda considerations whether these payers should not be enabled to have their tax base based on their profit determined according to International Financial Reporting Standards. We hold that such procedure would not only result in a reduction of administrative costs for payers, but it also seems that it would be a better solution with a view to the requirements as to the substantive regulation of taxes.

\section{References}

Aisbitt, S. (2002): Tax and accounting rules: some recent developments. European Business Review, vol. 14, no. 2, pp. 92-97.

Dvořáková, D. (2011): Finančni účetnictví a výkaznictví podle mezinárodnich standardi IFRS. (in English: Financial Accounting and Reporting Pursuant to IFRS Standards) 3. aktualizované a rozšířené vydání. Praha, Computer Press, 2011.

Dvořáková, V. a kol. (2013): Zdaňování př́jmi̊ fyzických a právnických osob 2013/2014. (in English: Taxation of the Income of Natural Persons and Legal Entities) Praha, Linde Praha a.s., 2013.

Eberhartinger, E. - Klostermann, M. (2007): What if IFRS were a Tax Base? New Empirical Evidence from an Austrian Perspective. Accounting in Europe. 2007, vol. 4, no. 2, pp. 141-168.

Fučík, I. (2012): Je účetnictví opravdu základem pro stanovení daňové povinnosti? (in English: Is Accounting Indeed the Foundation for the Determination of Tax Payments) [on-line], Economia, a.s., c2012, [cited 
Molín, J. - Jirásková, S.: Legal Consequences of the Determination of Corporate Income Tax Base Referring to IFRS.

$19^{\text {th }}$ October 2014], <http://download.ihned.cz/download/DOT_nwsltr/ FinManagement_2012_21.pdf>

Harvánek, J. a kol. (2013): Právní teorie. (in English: Legal Theory) Plzeň, Aleš Čeněk, 2013.

Jacobs, H. O. - Spengel, C. - Stetter, T. - Wendt, C. (2005): EU Company Taxation in Case of a Common Tax Base: A Computer-based Calculation and Comparison Using the Enhanced Model of the European Tax Analyzer. [on-line], Manheim, Zentrum für Europäische Wirtschaftsforschung Discussion Paper No. 5-37, 2005.

James, S. (2002): The Relationship Between Accounting and Taxation. Discussion Papers in Management, No. 02/09, University of Exeter.

Jaroš, T. (2013): Daň z př́jmů právnických osob v kontextu aktuální judikatury. (in English: Corporate Income Tax in the Context of Current Case Law) Praha, Wolters Kluwer ČR, a.s., 2013.

Kmec, J. a kol. (2012): Evropská úmluva o lidských právech. Komentár̆. (in English: European Human Rights Convention: Commentary) 1. vydání. Praha, C. H. Beck, 2012.

Kubátová, K. (2006): Daňová teorie a politika. (in English: Tax Theory and Policy) Praha, ASPI a.s., 2006.

Mejzlík, L. (2006a): Účetní informační systémy: využití informačních a komunikačních technologií $v$ účetnictví. (in English: Accounting Information Systems: Use of Information and Communication Technologies in Accounting) Praha, Nakladatelství Oeconomica, 2006, pp. 117-126.

Mejzlík, L. (2006b): Možnosti a rizika technologického řě̌ení převodu českých účetních závěrek do IFRS. (in English: The Possibilities and Risks of Technological Solution of the Conversion of Czech Financial Statements into IFRS) Český finanční a účetní časopis, vol. 1, no. 1, pp. 84-98.

Mejzlík, L. (2011): Předmluva - Interpretace Národní účetní rady jako ,best practice" v $\check{C} R$ ? (in English: Foreword - Interpretation of the National Accounting Council as "Best Practice" in the Czech Republicú Český finanční a účetní časopis. 2011, vol. 6, no. 2, pp. 4-6.

Mejzlík, L. - Žárová, M. (2010): Czech National Accounting Boards as an Assurance of Best Accounting Practice? In: 6th Workshop on European Financial Reporting. Stirling, Univerzity of Stirling, 2010. 
Melzer, F. (2011): Metodologie nalézání práva. Úvod do právní argumentace. (in English: Methodology of Finding Law. Introduction into Legal Argumentation) 2. vydání. Praha, C. H. Beck, 2011.

Müllerová, L. - Vančurová, A. (2006): Daně v účetnictví podnikateli̊. (in English: Taxes in the Accounts of Entrepreneurs) Praha, ASPI a.s., 2006.

Müllerová, L. (2008): Účetní výsledek hospodaření a základ daně. (in English: Accounting Profit P Loss and Tax Base) Český finanční a účetní časopis. 2008, vol. 3, no. 2, pp. 91-95. Diskuse k článku: Eberhartinger, Eva - Klostermann, Margret: What if IFRS were a Tax Base? New Empirical Evidence from an Austrian Perspective. Accounting in Europe, 2007, vol. 4, no. 2, pp. 141-168.

National Accounting Council (2012): Stanovisko Národní účetní rady $k$ účetním aspektům rozsudku Nejvyššiho správního soudu čislo 5 Afs 45/2011-94 ze dne 19. dubna 2012. (In English: Position of the National Accounting Council with Respect to the Accounting Aspects of Supreme Administrative Court judgement no. 5 Afs 45/2011-94 of 19 April 2012) [on-line], Národní účetní rada, c2012, [cited 19 ${ }^{\text {th }}$ October 2014], <http://www.nur.cz/media/Stanovisko_NUR.pdf>

Oestreicher, A., Spengel, C. (2007): Tax Harmonisation in Europe: The Determination of Corporate Taxable Income in the EU Member States. ZEW Discussion Papers No. 07-035, pp. 39.

Ottův slovník naučný (1893): Ottův slovník naučný. Illustrovaná všeobecná encyklopaedie obecných vědomostí. Šestý díl. Praha, J. Otto, 1893.

Pavlíček, V. a kol. (2004): Ústavní právo a státověda. II. díl. Ústavní právo České republiky. Část 2. (in English: Constitutional Law and Science, Volume II, Constitutional Law of the Czech Republic, Part II) Praha, Linde Praha, a.s., 2004.

Pelc, V. - Pelech, P. (2014): Daně z př́jmů s komentářem 2014. (in English: Income Tax with Commentary, 2014) 14. aktualizované vydání. Olomouc, ANAG, 2014.

Pilařová, I. - Pilátová, J. (2013): Účetní závěrka, základ daně, finanční analýza podnikatelských subjektů roku 2013. (in English: Financial Accounts, Tax Base, Financial Analysis of Business Entities in 2013) 6. přepracované vydání. Praha, 1. VOX a.s., 2013.

Procházka, D. (2014): IFRS 15 Výnosy ze smluv se zákazníky. (in English: Income from Agreements with Customers) In Hora, M. - Vašeková, M. (ed.): Účetnictví a auditing $v$ procesu světové harmonizace. Praha, Nakladatelství Oeconomica, pp. 142-146, 2014. 
Molín, J. - Jirásková, S.: Legal Consequences of the Determination of Corporate Income Tax Base Referring to IFRS.

Ricardo, D. (1817): On the Principles of Political Economy and Taxation (1 ed.). London: John Murray. <http://books.google.bg/books?id= cUBKAAAAYAAJ\&dq=editions\%3Ay8vXR4oK9R8C\&pg=PR1\#v=one page $\& \mathrm{q} \& \mathrm{f}=$ true $>$

Schanz, D. - Schanz, S. (2010): Finding a New Tax Base for German Companies after the Abolishment of the One-Book System. In: European Accounting Review, 2010, vol. 19, no. 2, pp. 311-341.

Skálová, J. - Žárová, M. (2013): Národní účetní rada a její vliv na české účetnictví. (in English: National Accounting Council and its Impact on Czech Accounting) Český finanční a účetní časopis, 2013, vol. 8, no. 3, pp. 6-19.

Sládeček, V. a kol. (2007): Ústava České republiky. Komentár̆. (in English: Constitution of the Czech Republic. Commentary.) 1. vydání. Praha, C. H. Beck, 2007.

Smith, A. (1776): An Inquiry into the Nature and Causes of the Wealth of Nations. Project Gutenberg. 〈http://www.gutenberg.org/ebooks/3300>

Široký, J. (2013): Daně v Evropské unii. (In English: Taxes in the European Union) 6. aktualizované a přepracované vydání, včetně CD. Praha, Linde Praha, a.s., 2013.

Tepperová, J. - Kubantová, K.: Omezení a možnosti jednoho inkasního mista $v$ České republice. (In English: The Limitations and Possibilities of a Single Collection Point in the Czech Republic) Český finanční a účetní časopis, 2013, vol. 8, no. 1, pp. 61-76.

Vančurová, A. - Láchová, L. (2010): Daňový systém ČR 2010. (In English: Tax System of the Czech Republic 2010) 10. aktualizované vydání, Praha, 1. VOX a.s., 2010.

Vančurová, A. - Láchová, L. (2014): Daňový system ČR 2014. (In English: Tax System of the Czech Republic 2014) 12. aktualizované vydání. Praha, 1. VOX a.s., 2014

Vašek, L. (2013): Použití IFRS v rozsahu českých účetních předpisů. (In English: Use of IFRS Within the Scope of Czech Accounting Regulations) In: Randáková, M (ed.). Sbornik pedagogické konference 2013. Rekodifikace práva. Praha, Nakladatelství Oeconomica, pp. 67-82, 2013.

Vítek, L. (2013): Zdanění firem a jejich daňový základ v České republice. (In English: Taxation of Companies and Their Tax Base in the Czech Republic) Český finanční a účetní časopis, 2013, vol.. 8, no. 2, pp. 38-49. 
Žárová, M. - Mejzlík, L. (2009a): Have IFRS Positive Impact on the Regulatory Accounting Systems in Continental European Countries? European Financial and Accounting Journal, 2009, vol. 4, no. 1, pp. 5-24. Žárová, M. - Mejzlík, L. (2009b): Irrationality of IFRS implementation into national accounting standards. Accounting in Europe. Catania, 10.09.2009 - 11.09.2009. Catania : University of Catania, 2009, pp. 21

Žárová, M. - Mejzlík, L. (2011): Could partial IFRS implementation into national accounting systems bring any positive impact? In: 7th Workshop on European Financial Reporting. Bamberg, 08.09.2011 - 09.09.2011. Bamberg: University of Bamberg, 2011, pp. 18. 


\title{
Legal Consequences of the Determination of Corporate Income Tax Base Referring to IFRS
}

\begin{abstract}
This paper is concerned with certain legal consequences of the determination of corporate income tax base. The introductory part analyses the term tax, discusses the constitutional dimensions of taxation, and formulates requirements as to tax legislation. The subsequent part of the contribution discusses the structure of corporate income tax base of those taxpayers, which keep accounting records. Special emphasis is placed on the relationship of accounting revenues and income that is subject to tax. The topic is set in the context of Czech Supreme Administrative Court case law, as the Court has been previously concerned with the issue. Next, we explore the specifics of the determination of a tax base of those taxpayers that are accounting entities, preparing their statutory financial statements in compliance with International Financial Reporting Standards (IFRS).
\end{abstract}

Key words: Corporate income tax; Tax base; Taxable income; International Financial Reporting Standards.

JEL classification: $\mathrm{H} 25$, M48 